\title{
BURNOUT AMONG PUBLIC ADMINISTRATION EMPLOYEES DURING THE PANDEMIC
}

\author{
Łukasz SKIBA \\ Czestochowa University of Technology
}

\begin{abstract}
Burnout is an increasingly common phenomenon among employees. Its level is influenced, among others, by workload, competition, applying for promotion, higher salary, prestige or social respect. The recent pandemic and the widespread remote work in administration include: fear for the health and life of one's own and family members; fear of losing your job, and thus your source of income; the need to learn how to use new tools, applications, communicators; the need to reconcile many roles and the resulting responsibilities (e.g. caring for relatives - children and sick parents; caring for the home shopping, cleaning, cooking, washing, etc.) professional work.

Purpose: The aim of this article (in the theoretical part) will be to present the essence of burnout syndrome, along with its most common causes, symptoms, as well as how to prevent and counteract it. On the other hand, in the empirical part of the study, the level of burnout of the described professional group during the partial lockdown during the covid19 pandemic will be determined on the example of research conducted in a local government administration unit.

Design/methodology/approach: The research method was a survey, a sent (e-mail) survey technique, and a survey questionnaire was the tool.

Findings: It has been reported that $27.3 \%$ of the respondents who are employees of a public administration unit are at the 5th (maximum) level of occupational burnout; $21.2 \%$ on level 4 ; and $30.3 \%$ at level 3 (feeling burned out). The main reason for burnout is: overwork + excess duties + professional stagnation $=78.8 \%$ of respondents' indications. On the other hand, the basic factors minimizing occupational burnout are: relaxation / rest (more often indicated by women), and hobbies / interests (favored by men).

Research limitations: The research was carried out using an electronic form sent by the secretariat via e-mail, to which only volunteers replied.

Practical implications: Counteracting burnout in the studied unit and helping to identify, prevent or counteract it in others.

Social implications: Work-live balance ("healthier" relationships in families); reduction of outlays for the treatment of employees and costs related to their absenteeism improving the atmosphere at work; quality of work (including customer service).
\end{abstract}

Key words: burnout, public administration, covid-19 pandemic.

\section{Introduction}

Burnout syndrome usually occurs in a situation of prolonged work-related stress that the individual cannot deal with. The occurrence of this phenomenon is especially favored by work in professions, the specificity of which consists in direct contact with people, e.g. working in the health service (doctors, nurses, orderlies, rescuers and others); fire brigade employees; the police; troops and similar professions that cannot be performed only remotely (on-line).

https://doi.org/10.11118/978-80-7509-820-7-0285 
Initial emotional involvement in work motivated by e.g. with the right thing, social respect, makes the employee more efficient than it used to be on a daily basis, which usually results in burdening him with new duties. However, if such a stressful situation, in which human life is often at stake, protracts in time and is additionally accompanied by the pressure of the result combined with work overload, as a result of which private life obligations are neglected, as well as the lack of recognition and adequate remuneration, then it is likely that such an employee will experience burnout.

Long-term performance of responsible, stressful, physically overloading work, without specific compensation (money, vacation, promotion), makes the so-called soft measures of motivation (e.g. praise from the superior) become ineffective, especially when the results of work from the employee's perspective are mediocre and external criticism appears. All this ultimately results in a loss of personal commitment, i.e. burnout in the profession.

Working in conditions of constant stress (especially in the conditions of the crisis such as the covid-19 pandemic) and the need to comply with the adopted procedures and regulations, make employees less flexible and creative, which leads to lower self-esteem, deterioration of health (initially mental, then physical) as well as decreased performance.

The general decrease in energy and the level of commitment also negatively affects the number and quality of contacts with served customers. Due to their own ailments, the employee ceases to notice the problems and needs of other people, ignores them and hyperbolizes their own. In addition to the decline in the quality of the services provided, the decline in psycho-physical condition results in greater susceptibility to depression, which in turn leads to escape to alcohol, drugs, drugs, etc.

Burnout generates a number of social effects, such as: treatment costs (mental and physical); possible family tragedies and relationship breakdowns; accidents at work and the need to pay compensation; or in this context, the most trivial drop in the quality of customer service.

The time of the pandemic crisis particularly intensified the occurrence of the discussed phenomenon of occupational burnout in organizations. Only a quick and at the same time accurate diagnosis of burnout allows you to take appropriate measures to prevent or combat this syndrome and its effects.

\section{The phenomenon of occupational burnout - characteristics, causes, prevention}

Burnout as a phenomenon can be analyzed on many levels, as it is an interdisciplinary issue, mainly in the field of psychology (clinical, social, work, personality) and management (HRM, organization).

According to literature sources, the author of the term Burn-Out is Graham Green, who in 1961 was the first to use this term to name the phenomenon he describes. (Green, 1961) On the other hand, Hubert J. Freuberg is considered to be the creator 
of the burnout syndrome, who in 1974 characterized the clinical patterns of burnout from the psychoanalyst's point of view. (Freuberg, 1974)

Particularly noteworthy are the works of Christina Maslach, who, although in 1981 together with Susan E. Jackson, developed a tool to measure occupational burnout (Maslach Burnout Inventory - MBI), it was only in the 90s that this psychologist managed to popularize in-depth research on occupational burnout among people representing professions related to social services, as well as helping other people.

Ch. Maslach defined occupational burnout as a response of the human organism, which functions in conditions of mental overload of professional work. Describing the phenomenon of burnout at work, the author draws attention to its three components: emotional exhaustion, depersonalization, and a decrease in the assessment of one's own achievements, as shown in Table 1.

Table 1. Characteristics of the components of occupational burnout according to Ch. Maslach.

\begin{tabular}{|l|l|l|l|}
\hline & \multicolumn{3}{|c|}{ Components / indicators of occupational burnout } \\
\hline & $\begin{array}{l}\text { emotional } \\
\text { exhaustion }\end{array}$ & $\begin{array}{l}\text { depersonalization } \\
\text { (dehumanization) }\end{array}$ & $\begin{array}{l}\text { decrease in the } \\
\text { assessment of own } \\
\text { professional } \\
\text { achievements }\end{array}$ \\
\hline $\begin{array}{l}\text { characteristics } \\
\text { of the } \\
\text { phenomenon }\end{array}$ & $\begin{array}{l}\text { tiredness and the } \\
\text { feeling that you can } \\
\text { no longer give } \\
\text { anything more of } \\
\text { yourself to others }\end{array}$ & $\begin{array}{l}\text { attitude of indifference to } \\
\text { others, impersonal } \\
\text { treatment, negative / } \\
\text { soulless attitude towards } \\
\text { people (who need help) }\end{array}$ & $\begin{array}{l}\text { viewing your own } \\
\text { work in a negative } \\
\text { light; } \\
\text { loss of satisfaction } \\
\text { and commitment to } \\
\text { professional work }\end{array}$ \\
\hline symptoms & $\begin{array}{l}\text { decreased activity, } \\
\text { feeling of psycho- } \\
\text { physical fatigue, } \\
\text { pessimism, } \\
\text { irritability, } \\
\text { discouragement to } \\
\text { work, constant } \\
\text { tension, lack of } \\
\text { interest in } \\
\text { professional } \\
\text { matters }\end{array}$ & $\begin{array}{l}\text { an attempt to distance } \\
\text { oneself from problems } \\
\text { concerning people from } \\
\text { the environment, which is } \\
\text { expressed in short and } \\
\text { formalized contacts, } \\
\text { distance, reduction of } \\
\text { involvement in relations } \\
\text { with people from work; } \\
\text { cynicism and blaming } \\
\text { others for their failures }\end{array}$ & $\begin{array}{l}\text { feelings of defeat } \\
\text { low self-esteem, loss } \\
\text { problem-solving } \\
\text { ability, aggression } \\
\text { and even leaving } \\
\text { work }\end{array}$ \\
\hline
\end{tabular}

Source: own study based on - Ch. Maslach, Wypalenie się: utrata troski o człowieka, [in:] P.G. Zimbardo, F.L. Ruch, Psychologia i życie, Wyd. Nauk. PWN, Warszawa 1994, s. 52.

Polish scientist Helena Sęk uses a similar context as Maslach. He states that people working in professions with close interpersonal contact and commitment, such as a doctor, nurse, therapist, teacher, policeman, priest, social worker, manager, etc. are particularly exposed to burnout. Psychological stress is part of the specificity of the above-mentioned professions, the continuous and long-lasting operation of which destroys the employee's body. Commitment to work means that the employee 
gives more of himself to others than he receives himself, and therefore his mental and physical resources decrease and burn out. (Cherniss, 1993) This is especially true for ambitious people with lofty goals, motivations, advancement, and a need for social significance. (Sęk, 2009, s. 84) (Ober, Karwot, 2017, s. 284)

Burnout (as opposed to trauma) occurs gradually as a result of fatigue, frustration and anxiety. Long-term presence of the above-mentioned leads to a state of depression, isolation and escape (e.g. into drugs, the virtual world, or a change of place of residence or work).

As mentioned before, the burnout syndrome occurs as a result of disproportions between workload, requirements, expectations and individual abilities to the amount, type and time of their endurance. (Litzke, Schuh, 2007, s. 167)

Basically, the causes of burnout can be grouped into three types: individual (personality, demographic, attitudes towards work); interpersonal; organizational. This breakdown is presented in detail in Table 2.

Table 2. Causes of occupational burnout

\begin{tabular}{|c|c|}
\hline \multirow{3}{*}{$\begin{array}{c}\text { Individual } \\
\text { (specific employee) }\end{array}$} & $\begin{array}{l}\text { personality: insecurity, passivity, dependence, low self-esteem, } \\
\text { defensiveness, psychopathic traits, immaturity, hysterical traits }\end{array}$ \\
\hline & $\begin{array}{l}\text { demographic: youth, higher education, loneliness, gender } \\
\text { ("exhaustion" in women, "depersonalization" in men) }\end{array}$ \\
\hline & $\begin{array}{l}\text { attitudes towards work: } \\
\text { - wholehearted commitment to work, } \\
\text { - high expectations of oneself, } \\
\text { - negating own load limits. }\end{array}$ \\
\hline \multirow{3}{*}{$\begin{array}{c}\text { Interpersonal } \\
\text { (employee - client, } \\
\text { employee - manager, } \\
\text { employee - associates) }\end{array}$} & $\begin{array}{l}\text { employee-client - too much emotional involvement in the } \\
\text { problems of the served persons; }\end{array}$ \\
\hline & employee -manager - bad communication; \\
\hline & $\begin{array}{l}\text { employee- associates - jealousy and rivalry (satisfaction with } \\
\text { the failures of others). }\end{array}$ \\
\hline \multirow{6}{*}{$\begin{array}{c}\text { Organizational } \\
\text { (working conditions) }\end{array}$} & - excessive workload, inability to cope with tasks, \\
\hline & - inability to exercise control over the work performed, \\
\hline & - insufficient remuneration in relation to the workload, \\
\hline & $\begin{array}{l}\text { - conflicts and lack of a good atmosphere at work, undermining } \\
\text { competences, }\end{array}$ \\
\hline & $\begin{array}{l}\text { - lack of justice in the workplace, discrimination or favoritism, } \\
\text { lobbying, }\end{array}$ \\
\hline & $\begin{array}{l}\text { - conflict of values, discrepancy between the goals of the } \\
\text { organization and the employee. }\end{array}$ \\
\hline
\end{tabular}

Source: own study based on - (Terelak, 2005, s. 229), (Grunt-Mejer, 2012), (Maslach, Leiter, 2011, s. 35-36), (Pabian 2017, s. 10-11), (Ober, Karwot 2017, s. 284) oraz (Hołyst 2013, s. 296).

As can be seen from the reasons for the occurrence of the burnout syndrome presented in Table 2, they may be dependent or independent of the employee. This is because burnout, although largely dependent on the psychological characteristics 
of the individual himself, is no less influenced by the environment in which a person has to work.

Since the causes of burnout are external and internal, the responsibility for counteracting it is the same. Referring to the observations of S.M. Litzke and $\mathrm{H}$. Schuh, the organization, management and employees (in relation to themselves and colleagues - Table 3) are responsible for preventing or preventing burnout from occurring. (Litzke, Schuh, 2007, s. 175-176)

Table 3. Subjects and areas of occupational burnout remediation activities

\begin{tabular}{|c|c|}
\hline \multirow{3}{*}{ organization } & $\begin{array}{l}\text { relieving employees, incl. by: appropriately longer breaks at work, } \\
\text { shortening the length of shifts, holidays, rotations, incomplete hours, }\end{array}$ \\
\hline & $\begin{array}{l}\text { adjusting the system of own needs to the system of employees' needs - a } \\
\text { matter of interests, autonomy and participation }\end{array}$ \\
\hline & $\begin{array}{l}\text { flattening the hierarchy and delegating responsibility - improving } \\
\text { motivation, communication and eliminating conflicts }\end{array}$ \\
\hline \multirow{5}{*}{ managers } & giving employees a model of behavior by their attitude \\
\hline & $\begin{array}{l}\text { providing the employee with the rationale and value of his actions } \\
\text { (appreciation, assigning a role) and support in achieving goals }\end{array}$ \\
\hline & not burdening urgent workers with additional tasks \\
\hline & irresistible praise and recognition \\
\hline & creating a friendly atmosphere in the workplace \\
\hline \multirow{3}{*}{ employees } & setting priorities at work \\
\hline & $\begin{array}{l}\text { distinguishing the requirements set by the organization from those } \\
\text { imposed on itself (saving time and overload) }\end{array}$ \\
\hline & commitment and success in the team (results in respect of colleagues) \\
\hline
\end{tabular}

Source: own study based on - (Litzke, Schuh, 2007, s. 175-176).

In addition to the measures listed in Table 3 for combating burnout, the following are mentioned: employee's access to psychological, physical, social and organizational resources offered by the place of employment (Grunt-Mejer, 2012); taking care of the psycho-physical health of the employee both by himself and the organization; having non-work related interests; separation of private and professional life; and keeping a distance to business tasks (Simpson, 2013, s. 187- 201).

\section{Methodology}

The research was conducted in March 2021, when remote work was in force and security rules were tightened due to covid-19. (https://www.gov.pl/...) The place of the survey was one of the commune offices in the Śląskie Voivodeship (in Poland).

To collect the data, a survey questionnaire consisting of 20 questions (plus a record: gender, age, length of service) was used, which was sent to the respondents electronically (e-mail) by the secretariat of the examined institution (due to the difficult pandemic situation, pilot studies were abandoned). The survey questionnaire used a five-point Likert response scale. 
33 people answered the questionnaire correctly: 25 women and 8 men; aged 25 to over 50 years of age; with work experience from 1-3 years to over 20 years.

The main aim of the study was to determine the level of burnout of the described occupational group during a partial lockdown during a pandemic. The specific objectives, on the other hand, concerned the identification of the main causes (areas) of burnout and the methods of prevention.

\section{Results}

When asked about the level of their own professional burnout, the respondents indicated answers which, quantitatively and in correlation with the length of service, are presented in Table 4.

\section{Table 4. Level of occupational burnout}

\begin{tabular}{|c|c|c|}
\hline $\begin{array}{c}\text { Burnout level } \\
\text { (1 - no burnout, } 5 \text { - complete burnout) }\end{array}$ & $\begin{array}{l}\text { Nr of responses } \\
\text { in } \%(\mathrm{~N}=33)\end{array}$ & Seniority \\
\hline 5 - complete burnout & $27,3 \%$ & $\begin{array}{l}\text { over } 20 \text { years }-15,2 \% \text {; } \\
11-20 \text { years }-9,1 \% \text {; } \\
6-10 \text { years }-3,0 \%\end{array}$ \\
\hline $4-$ on the verge of exhaustion & $21,2 \%$ & \multirow{3}{*}{$\begin{array}{l}\text { over } 1 \text { year, } \\
\text { and under } 6 \text { years of } \\
\text { age }\end{array}$} \\
\hline 3 - feels exhausted (warning level) & $30,3 \%$ & \\
\hline 2 - observes the occasional first symptoms & $18,2 \%$ & \\
\hline $\begin{array}{l}1 \text { - she had never seen such symptoms in } \\
\text { her life }\end{array}$ & $3,0 \%$ & $\begin{array}{l}\text { over } 1 \text { year, } \\
\text { and under } 3 \text { years }\end{array}$ \\
\hline
\end{tabular}

Source: own study of the research carried out.

In the five-point Likert scale, as many as $48,5 \%$ of respondents subjectively feel extreme exhaustion (4) or complete burnout (5), and 30,3\% feel exhausted (level 3). Only about $20 \%$ of respondents say it is completely or relatively free from burnout.

The main reasons for the appearance of this syndrome were indicated by the respondents as in Table 5.

Table 5. Causes of occupational burnout

\begin{tabular}{|l|c|}
\hline \multicolumn{1}{|c|}{ Cause of burnout } & $\begin{array}{c}\text { Number of responses in } \\
\text { \% }(\mathrm{N}=33)\end{array}$ \\
\hline changing the specifics of work from stationary to remote & $24,2 \%$ \\
\hline overwork + excess duties + professional stagnation & $78,8 \%$ \\
\hline excessive involvement in office work & $36,4 \%$ \\
\hline stress in the work environment & $63,6 \%$ \\
\hline lack of motivation to work & $54,5 \%$ \\
\hline irritation & $33,3 \%$ \\
\hline depressive moods & $42,4 \%$ \\
\hline anger and resentment & $9,1 \%$ \\
\hline sleep disturbance & $18,2 \%$ \\
\hline
\end{tabular}

Source: own study of the research carried out. 
The combination of overwork, excess duties and professional stagnation was indisputably recognized $(78,8 \%)$ as the main cause of burnout.

The top three, with the result of more than half of the responses, also included stress in the work environment and lack of motivation.

The level of general satisfaction of the respondents with the work performed is presented in Table 6.

Table 6. Job satisfaction

\begin{tabular}{|l|c|}
\hline \multicolumn{1}{|c|}{$\begin{array}{c}\text { Job satisfaction } \\
\text { 1 - no satisfaction, 5 - complete satisfaction) }\end{array}$} & $\begin{array}{c}\text { Number of responses in \% }(\mathrm{N}= \\
33)\end{array}$ \\
\hline 1 - lack & $15,1 \%$ \\
\hline 2 - low level & $30,3 \%$ \\
\hline 3 - average & $45,5 \%$ \\
\hline 4- noticeably & $9,1 \%$ \\
\hline 5 - complete & $0,0 \%$ \\
\hline
\end{tabular}

Source: own study of the research carried out.

The vast majority of respondents, $45,5 \%$, describe their job satisfaction as average (3). It is disturbing, however, that a similar amount (in total) feels its lack (1), or estimates it at a low level (2). Only 9,1\% of the respondents are noticeably (4) satisfied with their work, and no one marked complete (5) satisfaction.

In addition to the issues presented in Tables 4-6, the respondents were asked about the factors minimizing occupational burnout. In the first place there was relaxation / rest (indicated by about half of women and about a quarter less often by men), and hobbies / interests that men favor (about $50 \%$ ) and about $1 / 2$ less often women. Only one (out of 33) respondents admitted that they use alcohol or drugs to minimize burnout.

\section{Discussion}

In the available studies, there are various ways of understanding burnout (e.g. as a phenomenon in the work environment or as a disease - a clinical approach), and therefore identifying various factors that shape it. There are more and more research tools (questionnaires) used by various countries, organizations or scientists. They are given abbreviations derived from the full names (e.g.: MBI, LBQ, CBI, OLBI, SMBM, SQT, BODI, BAT, and other), in which the significance of the impact on occupational burnout is attributed to various degrees to various factors. (Eurofound, 2018)

The presented lack of unanimity among scientists causes a number of difficulties related to the comparison of this phenomenon in different countries at the methodological level without entering professional divisions yet.

Research from July 2020 by Monster (an online employment platform) shows that, despite occupational burnout, fewer and fewer people (59\% compared to the pre- 
pandemic situation) take their vacation. Moreover, $42 \%$ of people still working at home do not plan to take time off from work to regenerate. People seem to forget that a mental break from work is extremely important and can prevent burnout. (Monster, 2020) The results of these studies seem to be in contradiction to the responses of the respondents of the research presented in this study, who indicated rest, relaxation, developing interests, and practicing hobbies as a way of coping with burnout. This difference may result from the fact that people working in public administration are highly qualified, hence their fear of finding their way in the labor market is not that high.

Although there are differences in the methods of studying burnout and the results of these studies, there is also some agreement among scientists, and it concerns the fact that burnout most often affects people characterized by over-commitment and ambition, highly motivated, and setting high expectations. and striving for perfectionism. (Krawczyk-Sokołowska, 2008, s. 272) (Sęk, 2009, s. 84) (Hołyst, 2013, s. 296) (Ober, Karwot, 2017, s. 284)

\section{Conclusion}

Almost $80 \%$ of respondents have a problem with burnout, taking into account levels from 3 (feeling exhausted) to 5 (complete burnout). The level of burnout correlates with the seniority of the respondents (which confirmed the adopted research assumption): the longer the seniority, the higher the burnout level.

The results of the conducted research allow to conclude that the employees of the local government administration, despite the change in the way of working to the remote one as a result of the covid-19 pandemic, see this as the cause of burnout to a relatively low degree, because only about a quarter of the respondents. This could indicate that the vast majority of these employees are well trained, equipped and have no problems with operating modern equipment and applications for remote work.

The main causes of burnout, on the other hand, are perceived by the respondents as overwork, excessive duties and professional stagnation, i.e. heavy monotonous, routine work in a position without the possibility of promotion. In addition, stress in the work environment (which may result from errors related to human resource management, as well as concerns about health and work, and the ability to combine work at home with taking care of the household and loved ones, in particular children in the situation of covid-19), lack of motivation (resulting from low salary and focus on survival in the conditions of a pandemic crisis) and depressive moods $(42,4 \%)$, which should be considered a highly worrying symptom, the cause of which can be seen in lockdown, associated with closing at home and limiting social contacts.

Relaxation and having a hobby allow you to slightly reduce the level of burnout, but due to low earnings, they cannot be too fancy, and thus give you complete satisfaction.

As for job satisfaction, it was assumed in the research that it would correlate with the level of occupational burnout, but this was not entirely confirmed. Although only 
about half of the number of people who are completely burned out at work declare a total dissatisfaction with work, summing up three analogous levels, it turns out that the overall level of job dissatisfaction is higher than the level of occupational burnout. Hence, it can be concluded that along with the work experience, a group that does not derive any satisfaction from it will join the professionally burned out.

\section{References}

1. Cherniss C. (1993), Role of Professional Self-Efficacy in the Etiology and Amelioration of Burnout, [in:] Schaufeli W., Maslach C., Marek T. (eds.), Professional Burnout: Recent Developments in Theory and Research, Taylor \& Francis, London.

2. Freudenberg H.J. (1974), Staff burn-out, Journal of Social Issues, 30, 159-165. http://dx.doi.org/10.1111/j.1540-4560.1974.tb00706.x

3. Green G. (1961), A Burn-Out Case, Publisher: William Heinemann; 1st edition (January $1,1961)$

4. Grunt-Mejer K. (2012), Wypalenie zawodowe - czynnik obnizajacy poziom bezpieczeństwa w pracy, „Bezpieczeństwo Pracy. Nauka i Praktyka”, No 4.

5. Hołyst B. (2013), Zagrożenia ładu społecznego, Wyd. Nauk. PWN, Warszawa.

6. https://www.gov.pl/web/koronawirus/od-20-marca-w-calej-polsce-obowiazujarozszerzone-zasady-bezpieczenstwa

7. Krawczyk-Sokołowska I. (2008), Zasoby kadrowe jako podstawa innowacyjności przedsiębiorstwa, [in:] Herman A., Poznańska K. (eds.), Przedsiębiorstwo wobec wyzwań globalnych, Oficyna Wydawnicza SGH, Warszawa.

8. Litzke S.M., Schuh H. (2007), Stres, mobbing $i$ wypalenie zawodowe, Gdańskie Wydawnictwo Psychologiczne, Gdańsk.

9. Maslach Ch. (1994), Wypalenie się: utrata troski o czlowieka, [in:] P.G. Zimbardo, F.L. Ruch (eds.), Psychologia i życie, Wyd. Nauk. PWN, Warszawa.

10. Maslach Ch., Leiter M.P. (2011), Pokonać wypalenie zawodowe. Sześć strategii poprawienia relacji z praca, Wolters Kluwer Polska, Warszawa.

11. Ober J., Karwot J. (2017), Wypalenie zawodowe jako społeczna dysfunkcja w środowisku pracy, ,Zeszyty Naukowe Politechniki Śląskiej. Organizacja i zarządzanie”, z. 112. DOI: 10.29119/1641-3466.2017.112.24.

12. Pabian A. (2017), Godziwa płaca w zrównoważonym zarządzaniu zasobami ludzkimi, „Zeszyty Naukowe Politechniki Częstochowskiej. Zarządzanie”, No 28, t. 1. DOI: 10.17512/znpcz.2017.4.1.01.

13. Research report: Eurofound (2018), Burnout in the workplace: A review of data and policy responses in the EU, Publications Office of the European Union, Luxembourg.

14. Research report: Monster (2020) (https://www.monster.com/careeradvice/article/overworked)

15. Sęk H. (2009), Wypalenie zawodowe - przyczyny i zapobieganie, Wyd. Nauk. PWN, Warszawa.

16. Simpson D. (2013), Istota i konsekwencje ekonomiczne wypalenia zawodowego, „Biznes Międzynarodowy w Gospodarce Globalnej”, No 32, K. Bałandynowicz-Panfil (ed.), Wydawnictwo Uniwersytetu Gdańskiego, Sopot.

17. Terelak J.F. (2005), Psychologia organizacji i zarzadzania, Difin, Warszawa. 